\title{
Sotalol Hydrochloride
}

National Cancer Institute

\section{Source}

National Cancer Institute. Sotalol Hydrochloride. NCI Thesaurus. Code C29463.

The hydrochloride salt form of sotalol, an ethanolamine derivative with Class III antiarrhythmic and antihypertensive properties. Sotalol hydrochloride is a nonselective beta-adrenergic receptor and potassium channel antagonist. In the heart, this agent inhibits chronotropic and inotropic effects thereby slowing the heart rate and decreasing myocardial contractility. This agent also reduces sinus rate, slows conduction in the atria and in the atrioventricular (AV) node and increases the functional refractory period of the AV node. In the lungs, sotalol inhibits vasodilation and bronchodilation. In addition, this agent inhibits renin release. 